\title{
EFFECTS OF PHYSICAL AND CHEMICAL MODIFICATION ON BIOLOGICAL ACTIVITIES OF CHITOSAN/ CARBOXYMETHYLCELLUSE BASED HYDROGELS
}

\author{
SAIDA BENGHANEM*, ASMA CHETOUANI, MERIEM ELKOLLI, MAHMOUD BOUNEKHEL \\ \& DJAFAR BENACHOUR
}

Laboratory of Multiphasic and Polymeric Materials, Faculty of Technology, Ferhat Abbas University-Setif-1, 19000 Setif-Algeria.

\begin{abstract}
Hydrogels network based on carboxymethylcellulose (CMC) and chitosan (CS), CC1 and CC2, have been prepared respectively in the presence or without the crosslinking agents [(N-hydroxysuccinimide (NHS)/N,N'-dicyclohexylcarbodiimide (DCC)] and characterized by FT-IR.

The swelling behavior in distilled water at $25^{\circ} \mathrm{C}$ and biological activities have been investigated. CC1 hydrogel revealed higher potential swelling than CC2. Hydrogels showed to possess an important antioxidant activity equal to $66.67 \%$ for $\mathrm{CC} 1$ and $57.27 \%$ for CC2, to scavenge hydroxyl radicals at $2 \mathrm{mg} / \mathrm{mL}$. And the values of their reducing power were approximately $53 \%$ and $57 \%$.

From the hemolytic potential test the obtained materials were hemo-compatible. The anti-inflammatory activity exhibited that hydrogels were able to protect albumin from denaturation.
\end{abstract}

Keywords Chitosan; Carboxymethylcellulose; Hydrogels; Swelling; Biological activities.

\section{INTRODUCTION}

Hydrogels are hydrophilic polymers but they remain insoluble due to chemical or physical crosslinks between individual polymeric chains ${ }^{1}$. Both natural and synthetic polymers can be used for the synthesis of hydrogels, achieved by methods such as physical gelation, chemical cross-linking or selfassembly ${ }^{2}$. Hydrogels are used in various domains including the biomedical, biotechnology, pharmaceutical and separation technology. They are soft, pliable, non-toxic, biodegradable and wet materials ${ }^{3}$.

Polysaccharides, the most abundant organic substances on the earth, are particularly important for preparation of hydrogels and play a role in domains involved in hydrophilicity, swelling, hydration, gelling...etc ${ }^{4}$.

Chitosan $(C S),[\beta-(1 \rightarrow 4)$-2-amino-2-deoxy-D-glucose $]$, is biodegradable polysaccharide obtained from partial deacetylation of chitin ${ }^{5,6}$. Chitosan is readily soluble in dilute acids at $\mathrm{pH}<6{ }^{7}$. The presence of polar groups $(-\mathrm{OH}$ and $-\mathrm{NH}_{2}$ groups) in the chemical structure means it is able to form secondary interactions with other polymers. Due to its biocompatibility, biodegradability and antibacterial properties, it is used in the fabrication of hydrogels, films and microspheres ${ }^{8}$, biomedical and cosmetic applications ${ }^{9,10}$.

Sodium carboxymethyl celllose $(C M C),[\beta-(1 \rightarrow 4)$-D-glucopyranose $]$, is an important industrial polymer ${ }^{11}$, produced by partial modification of cellulose with chloroacetic acid ${ }^{12}$. The presence of $\left(-\mathrm{CH}_{2} \mathrm{COO}-\right)$ groups conspicuously improve its solubility in water ${ }^{13}$. $\mathrm{CMC}$ is a typical weak acid polyelectrolyte (pKa $\square 3.8$ ). Due to the biocompatibility, biodegradability and non-toxicity of $\mathrm{CMC}$, it is used in pharmaceutical and biomedical applications and pulp cell regeneration ${ }^{14,15}$.

The aim of this work is the preparation and characterization of crosslinked hydrogels based on CMC and CS. Biological activities were examined by antioxidant, anti-inflammatory and hemolytic capacities of all these prepared biomaterials.

\section{MATERIALS AND METHODS}

Sodium $\mathrm{CMC}(\mathrm{MW}=250 \mathrm{kDa}, 8 \%$ moisture Sodium content, average viscosity of $400-800 \mathrm{cps}$ ), chitosan with $65 \% \mathrm{~N}$-deacetylation degree, DCC (N,N'-dicyclohexylcarbodiimide), NHS (N-hydroxysuccinimide) were purchased from Sigma-Aldrich. Other reagents were analytical grade and used without further purification.

\subsection{Amidation of CMC}

According to Matute et al. ${ }^{16}$ CC1 hydrogel was obtained by amidation reaction of CMC with chitosan in the presence of coupling agent (DCC and NHS) as shown below:

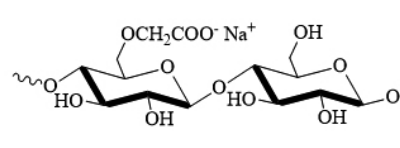

CMC

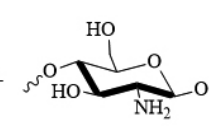

CS

In a $200 \mathrm{ml}$ beaker, $1 \mathrm{~g}$ of chitosan was dissolved in $100 \mathrm{~mL}$ of acetic acid $(1 \%)$ with stirring for 24 h. $0.1 \mathrm{M}$ of $\mathrm{NaOH}$ was added to adjust $\mathrm{pH}$ of the solution at 6.5. In the other hand, $5 \mathrm{~mL}$ of NHS $(0.18 \mathrm{~g} / \mathrm{mL})$ and $5 \mathrm{~mL}$ of DCC $(0.3 \mathrm{~g} /$ $\mathrm{mL})$ were added to $10 \mathrm{~mL}$ of an aqueous solution of $\mathrm{CMC}(0.15 \mathrm{~g} / \mathrm{mL})$, under contentious stirring for $1 \mathrm{~h}$. The obtained solution was mixed with chitosan

With NHS/DCC at $\mathrm{pH}=6.5, \mathrm{t}=72 \mathrm{~h}, \mathrm{Tamb}$

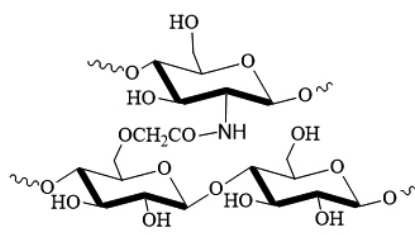

CCl (Chemical network)

solution and stirred for $72 \mathrm{~h}$. The resulting hydrogel $(\mathrm{CC} 1)$ was precipitated, washed with water/ethanol, isolated by centrifugation ( $300 \mathrm{rpm}$ for $10 \mathrm{~min}$ ), and air dried for three days.

The same procedure was followed to prepare the second hydrogel $\mathrm{CMC} /$ $\mathrm{CS}(\mathrm{CC} 2)$.

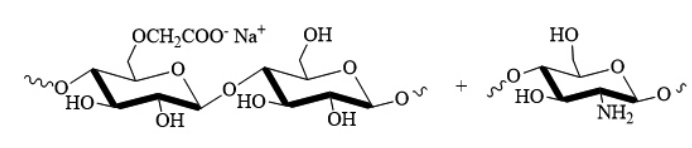

CMC

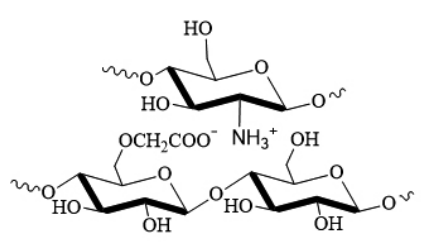

CC2 (Physical network) 


\subsection{Determination of free amino groups}

The number of amino groups was measured for CS, CC1 and $\mathrm{CC} 2$ by means of $\mathrm{pH}$ metric titration method ${ }^{4} .0 .1 \mathrm{~g}$ of each sample was dissolved in $(12.5 \mathrm{ml}, 0.1 \mathrm{~N}) \mathrm{HCl}$ and stirred for $24 \mathrm{~h}$. Then, the solution was titrated with $(0.1 \mathrm{~N}) \mathrm{NaOH}$. The percentage of amino groups was calculated using equation $(1)^{17}$.

$$
\mathrm{NH}_{2}(\%)=\left[\mathrm{M}_{\mathrm{NaOH}}\left(\mathrm{V}_{2}-\mathrm{V}_{1}\right) * \frac{161}{\mathrm{~W}}\right] * 100
$$

where:

$\mathrm{M}_{\mathrm{NaOH}}$ is the molarity of the $\mathrm{NaOH}$ solution, $\mathrm{V}_{1}$ and $\mathrm{V}_{2}$ the volume to neutralise the excess of $\mathrm{HCl}$ and the protonated amino groups, 161 is the molecular weight of the monomeric unit of chitosan and $\mathrm{W}$ is the mass of the sample in dry state before titration.

\subsection{Potentiometric and conductometric titration}

The contents of $-\mathrm{OCH}_{2} \mathrm{COOH}$ and $-\mathrm{NH}_{2}$ in $\mathrm{CC} 1$ and $\mathrm{CC} 2$ were determined following the method described by Dhar et al., ${ }^{18}$. Initially, the $\mathrm{pH}$ of each aqueous solution of hydrogel (1\%) was increased to 11 by addition of $\mathrm{NaOH}$ $(0,1 \mathrm{M})$. The solution was then titrated dropwise with $\mathrm{HCl}(0.1 \mathrm{~N})$. The $\mathrm{pH}$ and the electrical conductivity were measured simultaneously until $\mathrm{pH}$ of the sample approached 2.

\subsection{Fourier Transformed Infrared}

Spectroscopy Analysis FTIR spectra were acquired in transmission mode from powders and dried films (1\%). The spectra were recorded with a SHIMADZU 84005 spectrometer, in the range of $4000-400 \mathrm{~cm}^{-1}$ at a resolution of $4 \mathrm{~cm}^{-1}$. This analysis was conducted to observe changes of the functional group before and after interactions between polymer matrixes.

\subsection{Swelling test}

For swelling experiments, $80 \mathrm{mg}\left(\mathrm{W}_{0}\right)$ of each dried of prepared hydrogel were immersed in distilled water at $25^{\circ} \mathrm{C}$. The weight at different times (W) was determined and the swelling ratio (S) was calculated using the following equation:

$$
\mathrm{S}(\%)=\frac{\mathrm{w}_{\mathrm{t}}-\mathrm{W}_{0}}{\mathrm{w}_{\mathrm{o}}} * 100
$$

Where: $\mathrm{W}_{\mathrm{t}}$ and $\mathrm{W}_{0}$ are weights of the wet and dry samples, respectively.

2.6. Antioxidant activity assay

\subsubsection{Scavenging effect on hydroxyl radical}

The antioxidant activity of samples was evaluated using hydroxyl radical procedure ${ }^{19}$. Briefly, $0.2 \mathrm{~mL}$ of various concentrations $(0.25-2 \mathrm{mg} / \mathrm{ml})$ of (sample or ascorbic acid) was added into $0.2 \mathrm{~mL}$ of an aqueous solution of $\mathrm{FeSO}_{4}(5 \mathrm{mM})$. Then, $0.2 \mathrm{~mL}$ of an aqueous solution of $\mathrm{H}_{2} \mathrm{O}_{2}(1 \%(\mathrm{v} / \mathrm{v}))$ was added to the mixture, which was stirred again and incubated at $37^{\circ} \mathrm{C}$. After 60 min, $1 \mathrm{~mL}$ of distilled water was added, and the absorbance was measured at $510 \mathrm{~nm}$. The hydroxyl radical inhibition was calculated using the following equation:

$$
\text { hydroxyl radical inhibition }(\%)=\left(\frac{\text { A control-A sample }}{\text { A control }}\right) * 100
$$

Where, $\mathrm{A}_{\text {sample }}$ and $\mathrm{A}_{\text {control }}$ are the absorbances at $510 \mathrm{~nm}$ of $0.2 \mathrm{~mL}$ of the sample $(0.25-2 \mathrm{mg} / \mathrm{ml})$ or $0.2 \mathrm{~mL}$ of distilled water with $0.4 \mathrm{~mL}$ of a solution $(\mathrm{v} / \mathrm{v})$ of $\mathrm{FeSO}_{4}(5 \mathrm{mM}) / \mathrm{H}_{2} \mathrm{O}_{2}(1 \%)$.

\subsubsection{Reducing power determination}

The reducing power of samples was determined using the method described by Yen $\&$ Chen ${ }^{20} .1 \mathrm{~mL}$ of each sample with different concentrations $(0.25$ $2 \mathrm{mg} / \mathrm{mL})$ was mixed with $2.5 \mathrm{~mL}$ phosphate buffer $(0.2 \mathrm{M}, \mathrm{pH} 6.6)$ and 2.5 $\mathrm{ml}$ potassium ferricyanide $\left(\mathrm{K}_{3} \mathrm{Fe}(\mathrm{CN}), 1 \%\right)$. After incubation at $50{ }^{\circ} \mathrm{C}$ for 20 min, $2.5 \mathrm{~mL}$ trichloroacetic acid (TCA, 10\%) was added and the mixture was centrifuged for $10 \mathrm{~min}$ at $1000 \mathrm{rpm}$.

$2.5 \mathrm{~mL}$ of upper layer of solution was mixed with $2.5 \mathrm{~mL}$ of distilled water and $0.5 \mathrm{~mL}$ ferric chloride (1\%), and the absorbance was measured at $700 \mathrm{~nm}$. Vitamin $\mathrm{C}(\mathrm{Vc})$ was used as a positive control. The intensity of reducing power is directly proportional to the absorbance of the reaction mixture ${ }^{21}$.

2.7. Hemolytic potential

According to Fan et al., ${ }^{22}$ hemolytic potential (PH) of samples was determined using the following formula.

$$
\mathrm{PH}(\%)=\frac{\text { OD of sample-OD of negatif control }}{\text { OD of positif control }} * 100
$$

Where: OD is optical density.

2.8. In- vitro anti-inflammatory activity:

Anti-inflammatory activity of samples was evaluated by protein denaturation method as described by Alhakmani et al., ${ }^{23}$. Diclofenac sodium (powerful non steroidal anti-inflammatory drug) was used as a standard drug. $2 \mathrm{~mL}$ of two concentrations (100 and $200 \mu \mathrm{g} / \mathrm{mL}$ ) of samples or standard diclofenac sodium were mixed with $2.8 \mathrm{~mL}$ of phosphate buffered saline (pH6.4) and $2 \mathrm{~mL}$ of egg albumin (from fresh hen's egg). The obtained mixture was incubated at $27^{\circ} \mathrm{C}$ for $15 \mathrm{~min}$, and induced at $70{ }^{\circ} \mathrm{C}$ in water bath. The absorbance was measured at $660 \mathrm{~nm}$ using distilled water as blank. $2 \mathrm{~mL}$ of egg albumin and $2.8 \mathrm{~mL}$ phosphate buffer saline $(\mathrm{pH} 6.4)$ were used as a control test. The percentage inhibition of protein denaturation was calculated using the following formula:

$$
\text { inhibition }(\%)=\left(\frac{\text { Asample-Acontrol }}{\text { Acontrol }}\right) * 100
$$

Where: $\mathrm{A}_{\text {Sample }}$ : absorbance of tested sample; $\mathrm{A}_{\text {control }}:$ absorbance of control

\section{RESULTS AND DISCUSSION}

\subsection{Determination of free amino groups in the hydrogels}

The amount of $\mathrm{NaOH}$ between the first and the second jumping point was attributed to the amount of free amino groups. Fig. 1 shows the pH-titration of the CS and prepared hydrogels. The two steps at 2.5 and $12.5 \mathrm{ml}$ of $\mathrm{NaOH}$ $(0.1 \mathrm{~N})$ for chitosan are corresponding to $76.67 \%$ free amino groups which are insignificant in the case of $\mathrm{CC} 1$ and $\mathrm{CC} 2$ hydrogels. These results revealed the existence of interaction between $\mathrm{CMC}$ and CS.

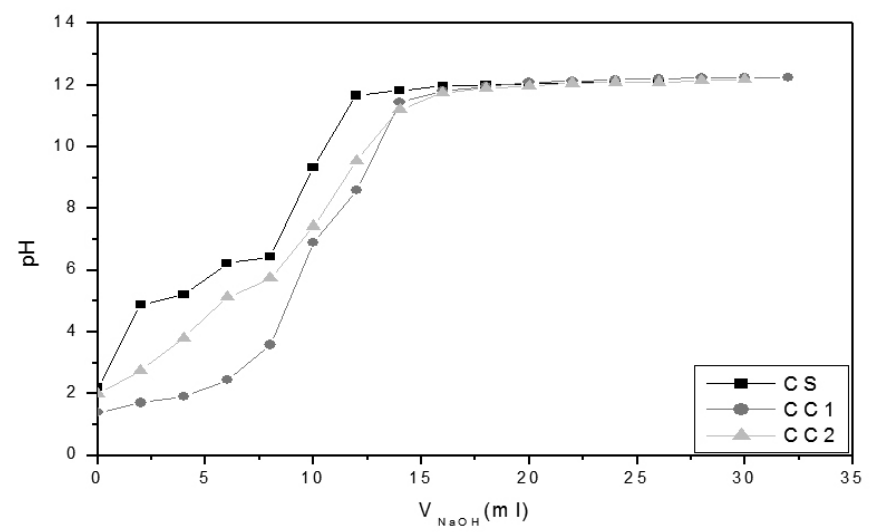

Fig. $1 \mathrm{pH}$ titration of $\mathrm{CS}, \mathrm{CC} 1$ and $\mathrm{CC} 2$.

\subsection{Potentiometric and conductometric titration}

The potentiometric and conductometric titration curves of $\mathrm{CC} 1$ and $\mathrm{CC} 2$ are shown in fig. 2 . The presence of different transition points are corresponding to $-\mathrm{OCH}_{2} \mathrm{COOH}$ and $-\mathrm{NH}_{2}$ functional groups on the hydrogels. $\mathrm{CCl}$ curve exhibits three transition points at $\mathrm{pH}$ equal to $9.5,4.8$ and 3.8 and four different regions which are corresponding to the neutralization of the excess of $\mathrm{NaOH}$, protonation of $\mathrm{OCH}_{2} \mathrm{COO}^{-}$on carboxymethylcellulose chains in the hydrogel, protonation of $-\mathrm{NH}_{2}$ groups of chitosan and excess acid present in the solution at $\mathrm{pH}>9.5,(9.5-4.8),(4.8-3.8)$ and (3.8-2), respectively. By measuring the moles of $\mathrm{HCl}$ reacted for each functional group (second and third transition regions), the amounts of $-\mathrm{OCH}_{2} \mathrm{COOH}$ and $-\mathrm{NH}_{2}$ were $0.25,0.78 \mathrm{meq} / \mathrm{g}$ respectively in $\mathrm{CC} 1$ and $0.33,0.83 \mathrm{meq} / \mathrm{g}$ in $\mathrm{CC} 2$. 
(a)

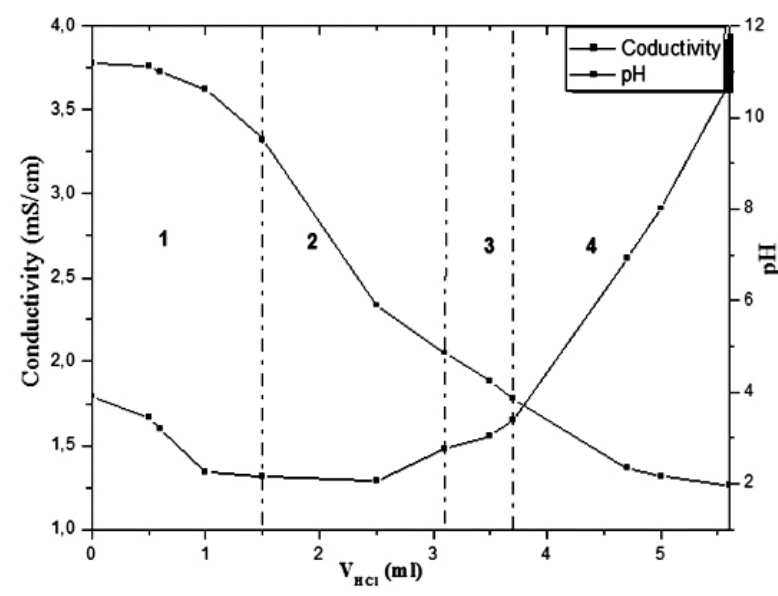

Fig. 2 pH and conductivity titration curve of (a): $\mathrm{CC} 1,(\mathrm{~b}): \mathrm{CC} 2$.

\subsection{Fourier transformed infrared (FTIR) spectroscopy}

The FTIR spectra (fig. 3) of CMC, chitosan, $\mathrm{CC} 1$ and $\mathrm{CC} 2$ show major changes in the functional groups of $\mathrm{CMC}$ due to the interaction with chitosan.

The CMC spectrum (fig. 3.a) exhibits bands at 3453, 2925, 2856, 1600, 1416 and $1323 \mathrm{~cm}^{-1}$ attributing to stretching vibration of $\mathrm{OH}$, asymmetric and symmetric stretching vibration of the aliphatic $\mathrm{CH}_{2}$ asymmetric and symmetric of the carboxylate groups (-COO-), and bending vibration of $\mathrm{CH}$, respectively ${ }^{24}$. The bands due to primary alcoholic $-\mathrm{CH}_{2} \mathrm{OH}$ stretching modes appeared at $1076 \mathrm{~cm}^{-1}$.

FTIR spectrum of chitosan (fig. 3.b) presents a broad O-H stretching band at $3445 \mathrm{~cm}^{-1}$. Characteristic bands for amide groups were found at 3445,1650 $\mathrm{cm}^{-1} 25$. The bands at 2925,2848 and $1380 \mathrm{~cm}^{-1}$ were assigned to $\mathrm{C}-\mathrm{H}$ links on chitosan chain ${ }^{26}$. The region from 1152 to $1081 \mathrm{~cm}^{-1}$ is the characteristic absorption of $\mathrm{C}-\mathrm{O}-\mathrm{C}$ linkage. Finally, $\mathrm{C}-\mathrm{N}$ fingerprint band appeared at $896 \mathrm{~cm}^{-1} 27$.

The IR Spectrum of $\mathrm{CC} 1$ (fig. 3.c) is completely different. New pics at $1625 \mathrm{~cm}^{-1}$ and $1571 \mathrm{~cm}^{-1}$ are attributing to $(\mathrm{v}(\mathrm{C}=\mathrm{O}))$ and $(\mathrm{v}(\mathrm{C}-\mathrm{N}))$ vibrations of amide I and amide II respectively ${ }^{28}$. Also, the band at $3322 \mathrm{~cm}^{-1}$ is corresponding to the axial stretching of the $\mathrm{O}-\mathrm{H}$ and $\mathrm{N}-\mathrm{H}^{29}$. The wide visible band at $631 \mathrm{~cm}^{-1}$ is due to $\mathrm{N}-\mathrm{H}$ out of the plane. This confirms the amidation of $\mathrm{CMC}$ by CS (i.e., conversion of $\mathrm{COOH}$ to CONHR) (fig. 4).

The IR spectrum of CC2 (fig. 3.d) exhibits the possibility of physical interaction between the positive charges derived from $\mathrm{CS}\left(\mathrm{CS}-\mathrm{NH}_{3}^{+}\right)$and the negative charges from $\mathrm{CMC}$ (CMC-COO-). A strong band at $1600 \mathrm{~cm}^{-1}$ is attributed simultaneously to asymmetric angular deformation of $\mathrm{COO}^{-}$ion and $\mathrm{NH}^{+}$groups.

\subsection{Swelling}

The swelling ratios $(\mathrm{S} \%)$ of hydrogels are represented in fig. 5. $\mathrm{CC} 1$ hydrogel exhibits maximum swelling $(\mathrm{S} \%) \approx 677 \%$ at $4 \mathrm{~h}$ and slightly decreases to $525 \%$ after $24 \mathrm{~h}$. However, ${ }_{\max } \mathrm{C} 2$ hydrogel shows $\mathrm{S}_{\max }$ equal to $542.5 \%$ during $1 \mathrm{~h}$ and then decrease rapidly to $350 \%$ due to, the network was discontinuous and the links between polymer chains of CMC and CS are physical and electrostatic.

\subsection{Antioxidant activity}

\subsubsection{Scavenging effect on hydroxyl radical}

Scavenging activity of hydrogels on hydroxyl radical was investigated using Fenton reaction. It was already known that hydroxyl radical generated by Fenton reaction was the most reactive of all the reduced forms of dioxygen and is thought to initiate cell damage in vivo ${ }^{30}$. According to results of scavenging effect on hydroxyl radical presented in fig.6, all the samples show a maximum values higher than $50 \%$ at $2 \mathrm{mg} / \mathrm{mL}: 66.67(\mathrm{CC} 1), 57.27 \%(\mathrm{CC} 2), 73 \%$ (CMC and $\mathrm{CS}$ ), and $94.63 \%$ (ascorbic acid). CC1 and $\mathrm{CC} 2$ reveal relatively lower anti-hydroxyl radical activity than the rest samples. Also, the scavenging effect of all our samples including ascorbic acid increased with increasing the concentration. (b)
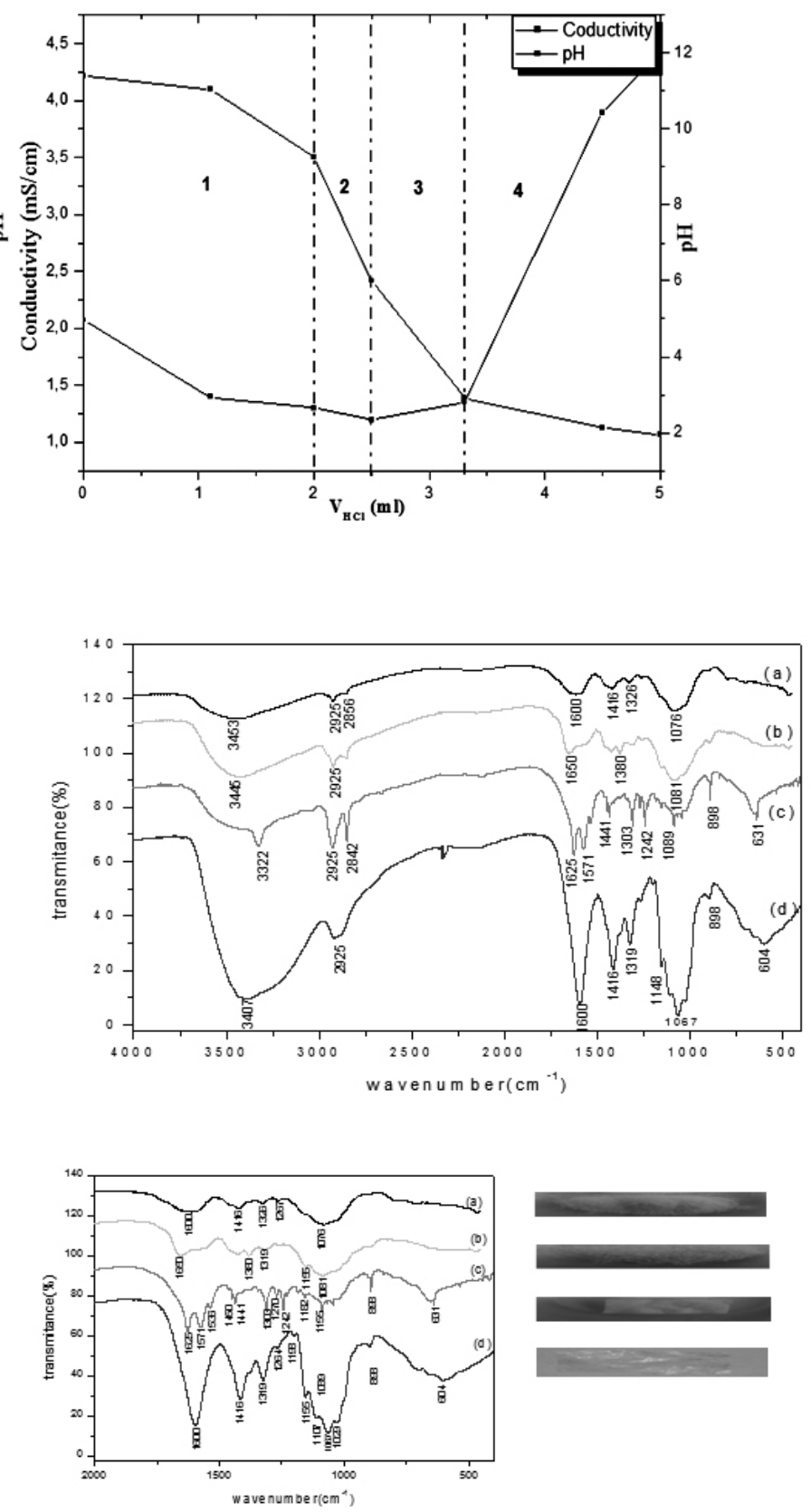

Fig. 3 FTIR spectra of (a): CMC, (b): CS, (c): CC1, (d): CC2.

As shown previously in different works, the presence of carboxyl ${ }^{19}$ and amino group ${ }^{31}$ on polysaccharide chains take undoubtedly part in free radicals scavenging and contributed to the antioxidant activity. So, the chemical and physical bonds between these groups decrease the scavenging activity probably due to the chelating affect of metal ions $\left(\mathrm{Fe}^{2+}\right)$.

\subsubsection{Reducing power determination:}

The antioxidant activity has been reported to have a direct, positive correlation with the reducing power ${ }^{32}$ and to be a simple, fast and reproducible test ${ }^{33}$. The reducing capacity of samples may serve as a significant indicator of its potential antioxidant activity. It was proved that the presence of the reducing agents caused the reduction of $\mathrm{Fe}^{3+} /$ ferricyanide complex to ferrous form $\left(\mathrm{Fe}^{2+}\right)$ which was monitored by measuring the formation of Perl's Prussian blue at 
$700 \mathrm{~nm}{ }^{34}$. As shown in fig. 7, the reducing power of samples correlated well with increasing concentration. The reducing power values of ferrocyanide ion, $\left(\left[\mathrm{Fe}(\mathrm{CN})_{6}\right]^{3-}\right)$, to ferrocyanide ion, $\left(\left[\mathrm{Fe}(\mathrm{CN})_{6}\right]^{4-}\right)$ for tested samples were determined: $0.64(\mathrm{CMC}$ and $\mathrm{CS}), 0.53(\mathrm{CC} 1)$ and $0.57(\mathrm{CC} 2)$, these results are in good agreement with scavenging effect on hydroxyl radicals.
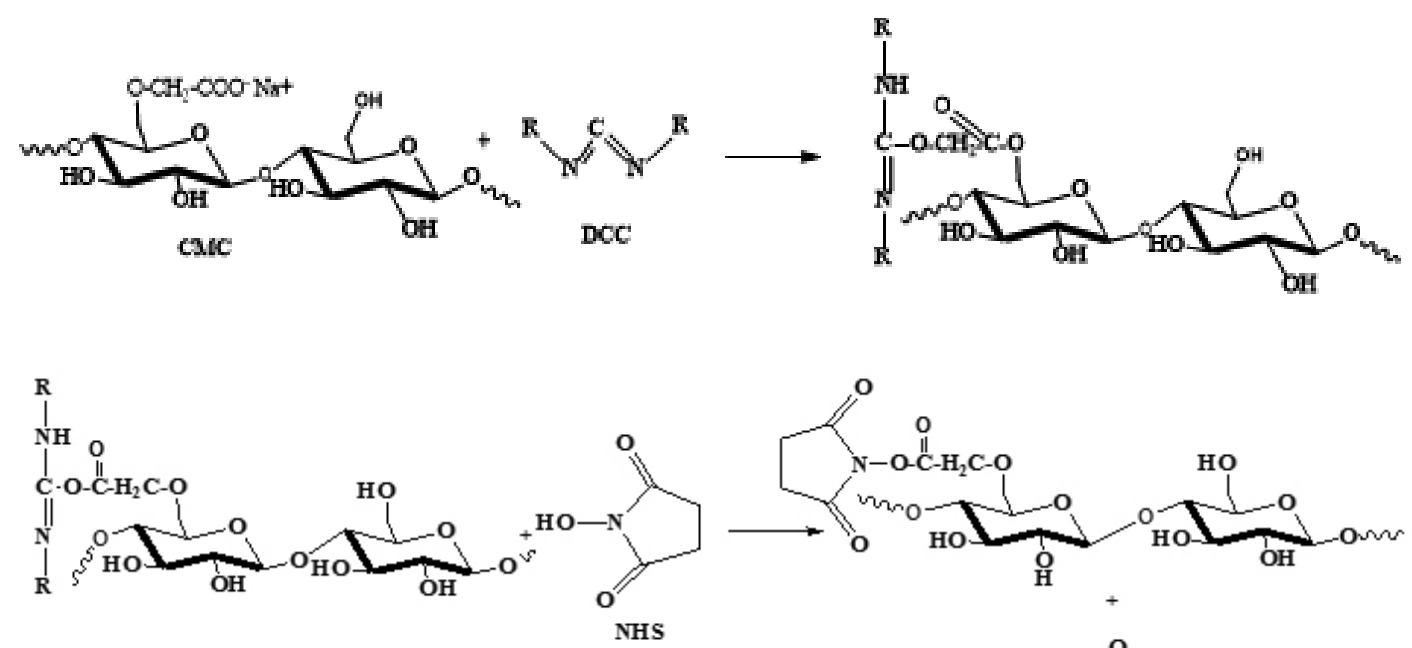<smiles>[R]NC(=O)NC</smiles>

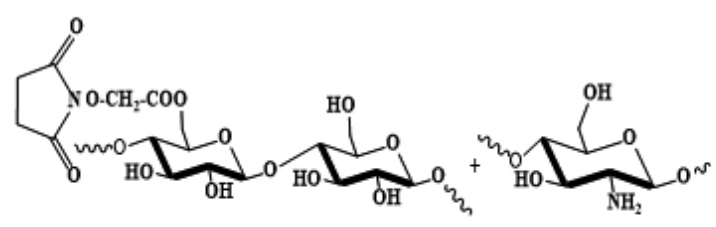

CS

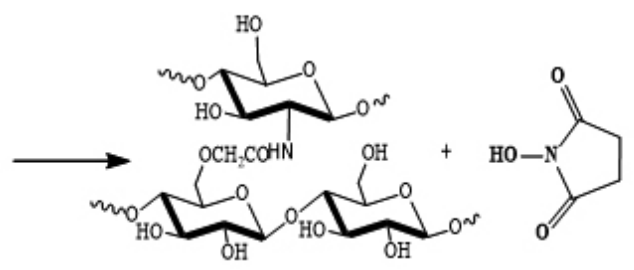

$\mathrm{CCl}$ (Chemical network)

$\mathrm{R}=\mathrm{C} 6 \mathrm{H} 11$

Fig. 4 Amidation of CMC by CS in presence of NHS/DCC.

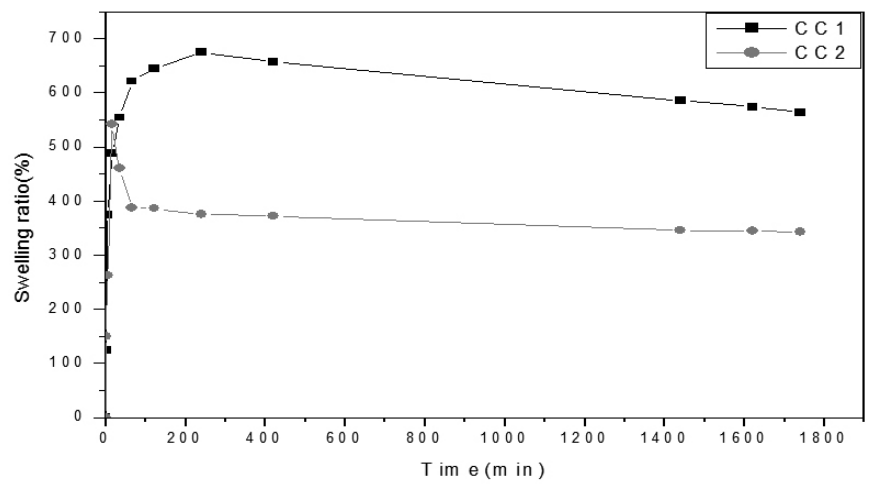

Fig. 5 Swelling ratio of prepared hydrogels at $25^{\circ} \mathrm{C}$.

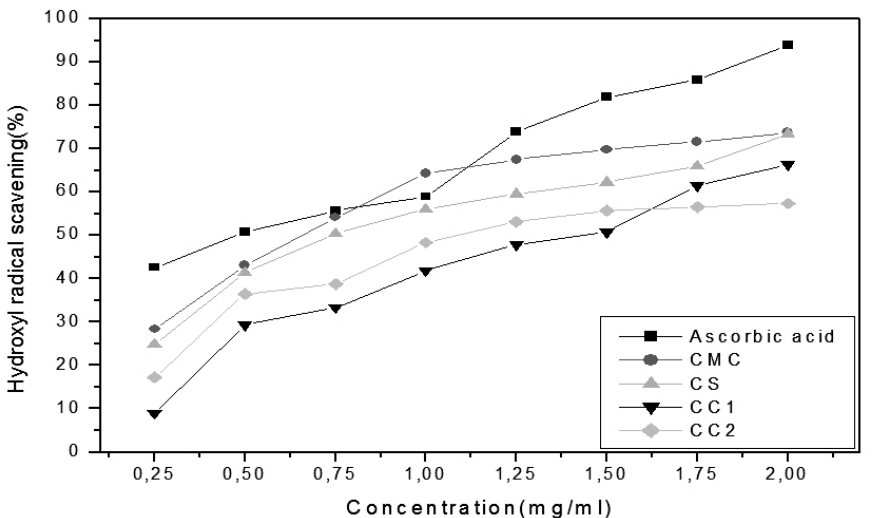

Fig. 6 Scavenging effect on hydroxyl radical. 


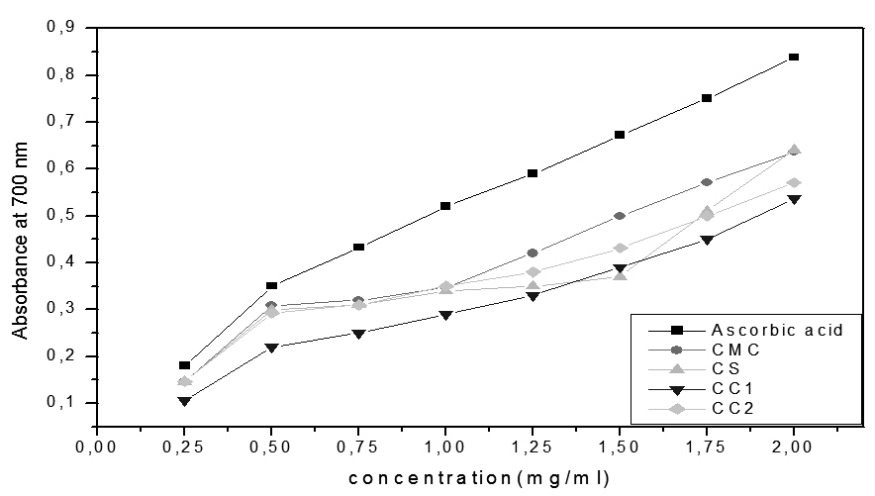

Fig. 7 Reducing power of samples and ascorbic acid.

\subsection{Hemolytic potential}

Hemolytic activity of materials was defined as the measure of the extent of hemolysis that may be caused by the material against normal human erythrocytes ${ }^{35}$. The Lysis of erythrocytes percentage of different samples at $37^{\circ} \mathrm{C}$ for $1 \mathrm{~h}$ is less than $10 \%$, as presented in table.1. Consequently, all tested samples are non hemolytic.

Table 1 Hemolytic potential of samples.

\begin{tabular}{|c|c|c|c|c|}
\hline Sample & CMC & CS & CC1 & CC2 \\
\hline Hemolysis (\%) & 0.3 & 5.07 & 4.35 & 4.85 \\
\hline
\end{tabular}

\subsection{In vitro Anti-inflammatory activity}

It has been demonstrated ${ }^{36}$ that the prevention of protein denaturation by medicinal agents under an in vitro experimental condition is an indication of anti-inflammatory effect, and consequently, this test would be worthwhile to use routinely for the preliminary screening of anti-inflammatory effect during the development process of studied product.

The mechanism of denaturation probably involves alteration in electrostatic, hydrogen, hydrophobic and disulphide bonding ${ }^{37}$. Table.2 presents the percentage inhibition values of albumin denaturation of samples and diclofenac sodium (reference) at (100 and $200 \mathrm{ug} / \mathrm{mL})$. It has been observed that the percentage inhibition increase with concentration.

Table 2 In-vitro anti-inflammatory effect of polymeric matrix/Diclofenac sodium.

\begin{tabular}{|c|c|c|}
\hline Samples & $\begin{array}{c}\text { \% inhibition }(100 \mu \mathrm{g} / \\
\mathrm{ml})\end{array}$ & $\begin{array}{c}\text { \% inhibition }(200 \mu \mathrm{g} / \\
\mathrm{ml})\end{array}$ \\
\hline $\mathbf{C M C}$ & 16.3 & 20.58 \\
\hline $\mathbf{C S}$ & 6.2 & 6.81 \\
\hline $\mathbf{C C 1}$ & 2.23 & 2.38 \\
\hline $\mathbf{C C 2}$ & 3.1 & 4.75 \\
\hline Diclofenac sodium & 50.8 & 81 \\
\hline
\end{tabular}

\section{CONCLUSION}

The physical and chemical crosslinking of CMC with Chitosan was successfully obtained in aqueous solution by casting method. The chemical network was prepared using DCC/NHS.

Infrared spectrophotometric analysis revealed the different interactions between $\mathrm{CMC}$ and $\mathrm{CS}$. The swelling data of $\mathrm{CC} 1$ hydrogel in distilled water at $25^{\circ} \mathrm{C}$ exhibit a higher stability than $\mathrm{CC} 2$ reaching $\mathrm{S}, 677 \%$.

In addition, biological assays showed that the prepared materials might be a potential candidate as antioxidant material due to the important hydroxyl radical scavenging and reducing power activities.

Therefore, all used hydrogels have no hemolytic effect against normal human erythrocytes. Thus, Owing to inhibitory effect of protein denaturation, these matrices would be useful in tissue engineering.

\section{REFERENCES}

1.- G. Buhus, M. Popa, J. Desbrieres, J. Bioact. Compat. Polym. 24, 525, (2009)

2.- S.R. Van Tomme, G. Storm, W.E. Hennink, Int. J. Pharm. 355, 1, (2008)

3.- N. Saha, A. Saarai, N. Roy, T. Kitano, P. Saha, J. Biomater. Nanobiotechnol. $2,85,(2011)$

4.- L.G. Gómez-Mascaraque, J.A. Méndez, M. Fernández-Gutiérrez, Acta. Biomater. 10, 798, (2014)

5.- A. Teotia, S. Ikram, B. Gupta, Polym. Bull. 69, 175, (2012)

6.- Y. Li, S. Zhang, X. Meng, X. Chen, G. Ren, Carbohydr. Polym. 83,130, (2011)

7.- V. Balan, L. Verestiuc, Eur. Polym. J. 53, 171, (2014)

8.- L. Weng, P. Rostamzadeh, N. Nooryshokry, H.C. Le, J. Golzarian, Acta. Biomater. 9, 6823,(2013)

9.- M. Dash, F. Chiellini, R.M. Ottenbrite, E. Chiellini, Prog. Polym. Sci. 36, 981, (2011)

10.- A. Di Martino, M. Sittinger, M.V. Risbud, Biomaterials 26, 5983, (2005)

11.- D.R. Biswal, R.P. Singh, Carbohydr. Polym. 57, 379, (2004)

12.- L. Fan, M. Peng, X. Zhou, H. Wu, J. Hu, W. Xie, S. Liu, Carbohydr. Polym. 112, 32, (2014)

13.- L. Fan, X. Zhou, P. Wu, W. Xie, H. Zheng, W. Tan, Q. Li, Int. J. Biol. Macromol. 66, 245, (2014)

14.- X.H. Zhao, X.W He, S.Q Xie, L.S. Yang, Appl. Mech. Mater. 20, 1157, (2010)

15.- H. Chen, M. Fan, J. Bioact. Compat. Polym. 22, 475, (2007)

16.- A.I.R. Matute, A. Cardelle-Cobas, A.B García-Bermejo, A. Montilla, A. Olano, N. Corzo, Food Hydrocoll. 33, 245, (2013)

17.- B. Hoffmann, D. Seitz, A. Mencke, A. Kokott, G. Ziegler, J. Mater. Sci. Mater. Med. 20, 1495, (2009)

18.- N. Dhar, S.P. Akhlaghi, K.C. Tam, Carbohydr. Polym. 87, 101, (2012)

19.- C. Delattre, G. Pierre, C. Gardarin, M. Traikia, R. Elboutachfaiti, A. Isogai, P. Michaud, Carbohydr. Polym. 116, 34, (2015)

20.- G.C. Yen, H.Y. Chen, J. Agric. Food. Chem. 43, 27, (1995)

21.- R. Subramanian, P. Subbramaniyan, V. Raj, SpringerPlus. 2, 1, (2013)

22.- L. Fan, Y. Sun, W. Xie, H. Zheng, S. Liu, J. Biomater. Sci. Polym. Ed. 23, $2119,(2012)$

23.- F. Alhakmani, S. Kumar, S.A. Khan, Asian. Pac. J. Trop. Biomed. 3, 623, (2013)

24.- H. Kono, Carbohydr. Polym. 106, 84, (2014)

25.- F.A. Al-Sagheer, E.I. Ibrahim, K.D. Khalil, Eur. Polym. J. 58, 164, (2014)

26.- S.M. Prabhu, S. Meenakshi, J. Water Process. Eng. 2, 96, (2014)

27.- M. Ibrahim, A.A. Mahmoud, O. Osman, A. Refaat, E.S.M. El-Sayed, Spectrochim. Acta. A Mol. Biomol. Spectrosc. 77, 802, (2010)

28.- A. Chetouani, M. Elkolli, M. Bounakhel, B. Djaafer, J. Chil. Chem. Soc. $59,2279,(2014)$

29.- H. Bidgoli, A. Zamani, M.J. Taherzadeh, Carbohydr. Res. 345, 2683, (2010)

30.- E. Rollet-Labelle, M.J. Grange, C. Elbim, C. Marquetty, M.A. GougerotPocidalo, C. Pasquier, Free Radic. Biol. Med. 24, 563, (1998)

31.- J.Y. Je, S.K. Kim, Biorgan. Med. Chem. 14, 5989, (2006)

32.- H. Osman, R. Nasarudin, S.L Lee, Food Chem. 86, 41, (2004)

33.- I.F. Benzie, J.J. Strain, Anal. Biochem. 239, 70, (1996)

34.- Y.C. Chung, C.T. Chang, W.W Chao, C.F. Lin, S.T. Chou, J. Agric. Food. Chem. 50, 2454, (2002)

35.- W. Dameshek, R. Schwartz, Ann. N. Y. Acad. Sci. 77, 589, (1959)

36.- S. Chandra, P. Chatterjee, P. Dey, S. Bhattacharya, Asian Pac. J. Trop. Biomed. 2, S178, (2012)

37.- Y.M. Bagad, A.R. Umarkar, A.U. Tatiya, S. J. Surana, J. Pharm. Res. 4, $1132,(2011)$ 